\title{
The Physician Louis Odier and the Medical Market in Geneva (1774-1817)
}

Philip Rieder

\section{Summary}

Louis Odier was an active physician in late Eighteenth century Geneva. Studying his medical practice conveys an idea of the social impact of a doctor on the local medical market at the time. He encountered a series of economic and professional difficulties for which he found original solutions. Convinced that the practicing physician was capable of offering the best services, he sought to defend professional interests. By his intellectual and public activities, he contributed to medical knowledge and to medical policies; in his practice and by his reflexive thought, he strove to draw the contours of an "ethical" professional figure.

Keywords: medical practice, Enlightenment, money and medicine, ethics

In the past twenty years, historians of Early Modern medicine have integrated the medical market model into their work in different ways. Some have used it to explain changes in consumer patterns; others have concentrated on particular settings, on "places", describing an open medical market of medical commodities. Although definitions of the concept are often hazy, it has been successfully used to bypass a constrained perspective focused on orthodox medical figures in favor of a larger vision including all types of medical actors and services. The consecutive explosion of information on medical practitioners conveys a better understanding of their practices and invites historians to focus on local contexts and traditions. The notion of market itself does affect the way we understand medical history and can induce misrepresentations of medical actors' roles. Generally speaking, it requires that historians tackle medical history from two points of view, that of the offer and that of the

Dr. Philip Rieder, Institut d'éthique biomédicale, Centre médical universitaire, Rue Michel Servet 1, CH-1211 Genève 4 (philip.rieder@unige.ch). 
demand. It also conveys a sense of bustling confusion that tends to infer synchrony rather than diachrony. ${ }^{1}$ The role played by the physician, paradoxically, has lost clarity as a series of historians have noted. Firstly, the medical market model suggests that, placed under the banner of medical offer, all practitioners were equal in the eyes of the sick, an idea that can only be alien to Early Modern society. ${ }^{2}$ Secondly, it invites historians to focus on paid services, excluding from the picture charitable and philanthropic activities which were at the core of many healers' practice. ${ }^{3}$ Finally, the model infers, uncritically, that the social practice of healing placed "competition for remunerative exercise" at the core of a learned physicians' social identity. ${ }^{4}$

Using specific concepts conditions the way medical history is written. Is it time to stray beyond the market model? Its usefulness in research is questionable, and yet the concept retains its pertinence when used to describe medical pluralism or to build a general frame for thinking out medical practices. For these reasons, I have adopted a pragmatic approach. Rather than throw the baby out with the bath water, I suggest that changes in scale, moving from the large-scale marketplace to the individual scale of a particular practitioner, is a means of saving the baby and disposing of some of the dirty water. ${ }^{5}$ Or, to be more to the point, introducing individual perspectives can reveal diachronic dynamisms within the marketplace, expose the effects of status on both patients and practitioners and, all in all, suggest a more complex market narrative. That said, theory is rarely self-sufficient in historical literature, and the following pages wrestle with issues relating subjective realities to a particular medical marketplace. Taking up the question over a long period of time would require examining a series of individual practitioners. In this article, I shall limit my attention to the late 18th century and to one physician.

Choosing the right practitioner is not a neutral step, but searching for sources tends to make a realist of the most imaginative historian. Archival reality did influence the choice of Louis Odier for this study. Odier was a Geneva-born and Edinburgh-trained physician. He was a member of a group of physicians who set up practices in Geneva in the 1770's where he remained an active practitioner until his death in $1817 .{ }^{6}$ Odier was not a common physi-

\footnotetext{
1 For an overview of recent literature, see Jenner/Wallis 2005.

2 Harley 1994, 398.

3 Wear 2000, 28f.

4 Broman 1995, 849.

5 On the theory of changes in scale, see Revel 1996. A handful of recent studies on individual physicians confirm that medical biographies do enhance our understanding of the Early Modern medical world. See Goubert 1992; Cook 1994; Siraisi 1997; Brockliss 2002.

6 On the establishment of this group, see Rieder/Louis-Courvoisier 2010.
} 
cian and he was proud of holding original views. He was also ambitious. Besides his practice as a physician, he was an active homme de lettres, an anglophile, an amateur banker, a medical researcher, a specialist in medical demography, a public figure and a philanthropist. However important Odier's input was, it remains on the "micro" side of the story. Before engaging seriously with his medical activities, it is necessary to introduce the larger picture, the "macro" reality of Geneva's 18th century medical market.

\section{A market view (1700-1820)}

Geneva's medical market as Odier found it when he set up his practice in the town in 1774, was conditioned by institutions and rules inherited from the 16th and 17th centuries. Some medical practices, those described at the time as "superstitious", were repressed and in fact difficult to find within the town. ${ }^{7}$ Orthodox practitioners had apparently a free field. The traditional tripartite organisation of medical healers was officially implemented in 1559 when a medical guild (Faculté) was founded: physicians, surgeons and apothecaries were attributed a theoretical monopoly over relevant activities. Reality was more complex. Irregular practitioners were admitted on shortterm licenses or tolerated in the immediate vicinity of the town. ${ }^{8}$ What is more, apothecaries and surgeons often worked as physicians, guiding patients through their illnesses. Despite energetic efforts made by the guild authorities to gain control over medical practice in the 18th century, the City Council remained in control. ${ }^{9}$ The feeble authority physicians had at the head of the guild was waning as master apothecaries and master surgeons strayed more than ever from their shops. Both groups profited from the legal limit of 10 surgical and 7 apothecary shops which they had petitioned for and been granted in $1700:{ }^{10}$ shops prospered under the supervision of qualified employees or partners; master apothecaries left their shops in order to visit patients ${ }^{11}$ and master surgeons rented out their shops to trained surgeons in order to concentrate on treating sick patients, mimicking the behavior of physicians. ${ }^{12}$

\footnotetext{
7 Rieder 2010.

8 See Rieder 2005; Louis-Courvoisier 2001.

9 Rieder/Tourn 2009.

10 Rieder 2009, $22 \mathrm{f}$.

11 Odier 2011, 49.

12 Rieder 2011.
} 
The dynamics of the marketplace appear to be in the hands of artisans, disrupted at times by the activities of irregular practitioners, and controlled by lay authorities. The narrative hereto is heavily influenced by contemporary emphasis on artisan and irregular healers, on practices rather than discourse. That said there were traditionally many physicians active in Geneva. ${ }^{13}$ Concentrations of physicians were particularly high on the eve of the 18th century. ${ }^{14}$ In 1700 , there were 16 physicians for a population estimated at 17000 , that is 1 physician for barely more than 1000 (1062) inhabitants ${ }^{15}$ and a very extraordinary 1 physician for less than 1000 inhabitants in $1710 .{ }^{16}$ What role did physicians themselves play on the local market? By emphasizing medical practices, irregular and subaltern practitioners, work on the medical marketplace has indirectly questioned traditional conceptions of the Early Modern physician without offering an alternative understanding. They did play a social role, were active in public health and supposed to treat the poor for free. ${ }^{17}$ And yet as a group, they left scant traces in court recordings, few personal documents and no shop inventories which could help us to grasp the practical nature of their activities. Beyond individual inputs into medical knowledge, the historical image of Geneva physicians for the period remains superficial. University-trained, and thus necessarily born to wealthy families, physicians did not always need to earn a living. Some were employed by the state in times of plague; others occupied part-time and badly paid positions at the General Hospital. Medical careers were based on private practice of which we know very little. Given what has been said of their social status, the term career may be an overstatement. Louis Odier's well-documented practice is an opportunity to explore the physician's economic choices and social strategies. It also suggests insights into changes in professional postures at the end of the Ancien Régime when the number of active physicians rose rapidly, doubling in a few years and putting an end to a 50-year decline in medical density (see fig. 1).

13 In 1569, for instance there were 8 physicians for a population upwards of 12000 . That is 1 physician for 1500 inhabitants. Data for the following years is less precise. An estimation based on the City Council's registers gives a mean number of 6.4 physicians between 1569 and 1640.

14 In France, according to Jean-Pierre Goubert, a city of Geneva's size (between 10000 and 20000 inhabitants) would have less than four physicians (3.65). For French localities, see Brockliss/Jones 1997, 522f.; Brockliss 2002, 127f.; Goubert 1977, 223.

15 Geneva's population in 1698 was 17250 . Perrenoud 1979, 38. Guild records enable a precise count of licensed physicians for the 18th century. Archives d'Etat de Genève (henceforward AEG), Santé F1.

16 There were 21 licensed physicians in 1710 for a population below 21000 inhabitants.

17 See the Ordonnances du 15 février 1658, «Ordonnances particulières pour les Docteursmédecins», art. 8, in Gautier 2001, 627. 


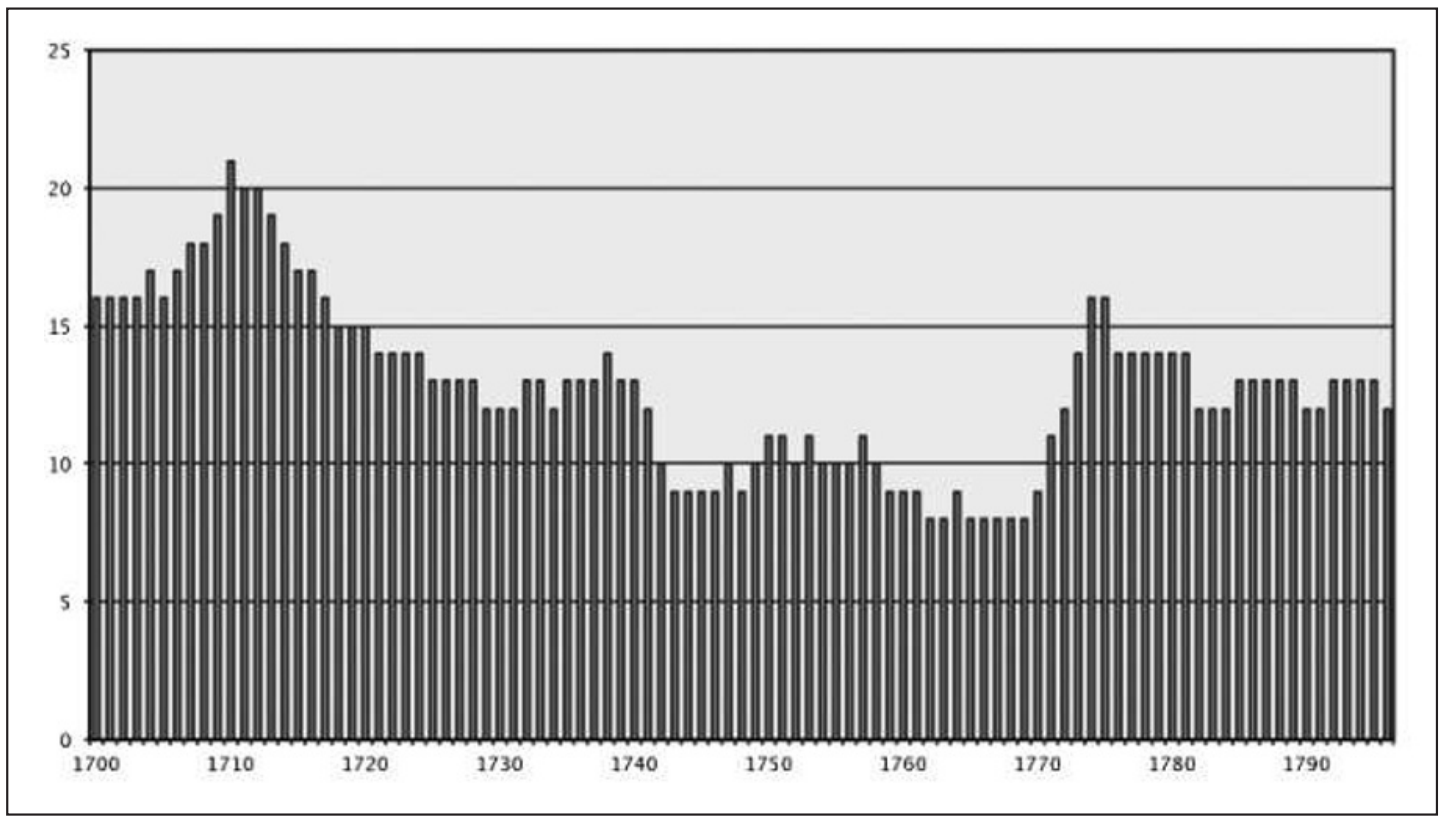

Fig. 1: Number of physicians practicing in Geneva between 1700 and 1798 (Source: AEG, Santé F1).

\section{Questioning a medical life}

Odier was one of eight young physicians who set up practices in Geneva between 1760 and $1780 .{ }^{18}$ Why did he choose a medical career? University matriculation records show that medical schools did attract growing numbers of students in the second half of the eighteenth century ${ }^{19}$ and Enlightenment discourse presented medicine as an important vehicle for contemporary aspirations and ideals. ${ }^{20}$ The path leading to Louis Odier's decision to become a physician suggests that medicine was then a desirable career for a welleducated youth. Born in a prosperous merchant family of strong Protestant conviction, Odier dreamed as a child of becoming a minister. As a teenager, he considered other opportunities. Law was the traditional choice for those who had renounced theology. In his letters, the young medical student explained to his friends that his father had actually taken the decision. His narrative starts with a question his father put to him on the career he planned to embrace. Odier answered that he saw three possibilities: commerce, law

18 Guillaume Solomiac (1740-1815); Daniel De la Roche (1743-1812); Charles-Guillaume Dunant (1744-1808); Gaspard Vieusseux (1746-1814); Louis Odier (1748-1817); Abraham Joly (1748-1812); Pierre Vignier (1747-1815); Jean-Louis Manget (1753-1809).

19 Julia/Revel 1989, 255-265; Bonner 1995, 39-41.

20 Risse 1992. 
or medicine. "You should not consider commerce or law," his father continued cautiously. "In that case", answered Odier, "I shall be a physician." 21 He had in fact decided earlier on. In 1765, Odier wrote two dissertations comparing careers in medicine, law and theology. The outcome was largely favorable to medicine and theology. ${ }^{22}$ Reading Jean-Jacques Rousseau's Emile a few months later seems to have put an end to Odier's aspirations to become a minister: he wrote a «confession de foi» (26 mai 1766) in which he enthusiastically exposed many of Rousseau's ideas, but only encountered disapproval from the local parson. ${ }^{23}$ For Odier's family, as for those of the three other young physicians who came from the same background, a medical career was a step in their ascension towards gentility, a means of entering elite circles and fulfilling intellectual ambition.

\section{Professional questions}

As a physician, Odier believed that traditional medical knowledge was insufficient and that contemporary clinical work, careful observation and the communication of results were the best basis for practice. He was convinced that amateur and irregular healers did harm patients. As a physician, he took part in, and was probably the initiator of a campaign against irregular healers in the last decades of the 18th century. ${ }^{24} \mathrm{In}$ his letters to his fiancée, he complained that many "sensible people" disregarded physicians in order to consult "charlatans and old women [comères]", "without even imagining that there could be the least risk to put their lives and their health in the hands of people whose very self-confidence should reveal their ignorance and presumption. [...] I moan and am outraged in silence at the weakness of the government which tolerates such abuses." ${ }^{25}$ Silence is not the best way to qualify his attitude to the authorities' permissibility. All petitions and letters against irregular practitioners found in Geneva's archives for this period were both signed by him and in his handwriting. As an employee, he contested the right of the Hospital directors to use the services of irregular practitioners to heal the sick poor, ${ }^{26}$ as a member of the guild, he protested that only physicians should be able to decide on the usefulness of new medical theo-

21 Unless otherwise stated, translations are by the author. BGE, Ms 5642/4, 13, Louis Odier à Stephen Pellet, [Edinburgh], 26.11.1768.

22 BGE, Ms fr 5644 / Cahier brun, VII. O. 19 décembre 1765 et VIII. O. 9 janvier 1766.

23 A copy of his «confession de foi» is conserved: BGE, Ms fr 5654,13-16.

24 This was not an isolated phenomenon. The campaign against irregular practitioners was led in France by the Société royale de médecine and later by the French authorities. See among others Kibleur 1999; Ramsey 1988.

25 Bibiliothèque de Genève (henceforward: BGE), Ms fr 4153, D 32, Jeudi-vendredi [1779].

26 BGE, Ms fr 4160, Jean-Jacques Manget, Daniel De la Roche et Louis Odier à François Lagisse, Genève, 25.5.1777. 
ries and as a future husband, he voiced distrust of "wise women"27. In all cases the argument was based on the capacity of judgment of academic physicians: "If we physicians," he wrote to his fiancée

who have made [medicine] our main occupation for many years, who have spared neither expense, time or effort to learn from the best masters and at great expense, who have overcome both disgust and exhaustion on many occasions in order to walk hospital wards, we who see sick people every day and combine with our experience those of all physicians who came before us by reading their books, if we, say I, are often confused, in danger of making mistakes, far from having an absolute confidence in our own knowledge, how could women who have done none of that, and who's knowledge is limited to having seen or heard of the success of a particular remedy or that it had done some good in such an occasion or to such a person, dare they counsel its use without worrying about possible consequences. ${ }^{28}$

Academic physicians alone, argued Odier, possessed the appropriate knowledge and experience to ensure that the patient received the best possible treatment. The campaign was totally ineffective, except maybe for the choice of his wife's medical advisors. The City Council continued de facto to control medical practice, the Hospital Directors were indignant that simple employees dare criticize their choices and, probably more importantly, in everyday life many situations showed that when physicians were at a loss, other practitioners had solutions. Physicians themselves could not ignore the phenomenon. Odier, for instance, explained how his colleague Gaspard Vieusseux's son had suffered from a sore knee.

He could not for the life of him stretch his leg. [...] But when his father was out, the woman who keeps his house in town during the summer and who is also a professional bone setter [rhabilleuse], took off the cataplasm and grumbled about the ignorance of physicians and surgeons who were going to maim the poor child, and undertook to cure him herself. She manipulated his knee, gave him no pain, and when his father returned, he found that his son could stretch and bend his knee which was almost cured. He accepted to let the woman pursue the cure. ${ }^{29}$

Odier would logically turn to colleagues to care for his own family, but sometimes, as here, University-trained physicians themselves could be compelled to call on the services of alternative healers.

\section{Economic reality?}

Odier and his seven young colleagues planned to earn money practicing medicine. Was this a matter of honor or necessity? All young physicians came from economically affluent families. The cost of years of study abroad was a considerable investment. ${ }^{30}$ Was it a good one? The story of a single medical

27 AEG, Registre du Conseil 288, p. 247, le 26.2.1785.

28 BGE, Ms fr 4158, S 29 Louis Odier à Andrienne Lecointe, s. d. [1779].

29 BGE, Ms fr 4155, H 18, Louis Odier à Andrienne Odier Lecointe, Genève, 6.7.1787.

30 There was no medical school in Geneva before 1876. Boarding and lodging students was expensive as were university costs. For examples of prices: Ramsey 1988, $50 \mathrm{f}$. 
career is not sufficient to answer the whole question, but it can contribute to bring the picture into focus. The first point to consider is whether a young physician had to earn a living. In Odier's case, it seems obvious that he was to depend on medicine for a livelihood. In fact, the vocational question asked by his father was not "what do you intend to study?", but "how do you plan to earn a living?". ${ }^{31}$ When he married, his father gave him a considerable sum in cash, 20000 livres courantes de Genève. This was not an uncommon gesture; many of his colleagues received similar sums. ${ }^{32}$ That said, 20000 livres courantes was not a fortune and as a source of income, insufficient to live in Geneva's elite circles. It is true that when added to a wife's dowry, the sum could yield quite a solid income..$^{33}$ This was not Odier's case. His wife's dowry was small (8000 livres courantes) and most of it was only due to be paid after her mother's death. ${ }^{34}$

How much money did Odier need? Reconstructing costs of living is a complex endeavor. In the 18th century, the bare minimum cost of feeding a person was at least 7 sols per day in Geneva. ${ }^{35}$ Evaluations of what food would cost a family of the middling sort are higher. A credible estimation for a family with three small children in nearby Lausanne comes close to 1.5 livres courantes per day. ${ }^{36} \mathrm{~A}$ couple, such as Odier and his wife, used to a luxurious lifestyle might spend a little more. Something like 2 livres courantes per day or 730 livres courantes $(2 \times 365)$ per year are possible estimates. This seems to be correct as between 1774 and 1778, Odier's parents-in-law lodged and boarded the couple for a sum between 850 and 1000 livres courantes per year. ${ }^{37}$ The sum would barely have covered the cost of their boarding, but was placed logically just within their actual financial capacities. The value of rent may have counted as informal support by family. Adding the costs of clothing, travel and everyday expenses brings the total expenses of the couple to something higher than the revenue of 964 livres courantes that the couple could expect in 1774 ( $4 \%$ of their fortune of about 22000 livres courantes) and was clearly insufficient to guarantee a comfortable and independent

31 BGE, Ms 5642/4, 13, Louis Odier à Stephen Pellet, [Edinburgh], 26.11.1768.

32 Physicians often married shortly after their studies. See Goubert 1992, 58-61; Rieder/LouisCourvoisier 2010. Esprit Calvet is here an exception: Brockliss 2002, 50.

33 Gaspard Vieusseux, for instance, was quite free from financial worries at the outset of his career. Although his father gave him considerably less money than Odier's father (6000 livres courantes), his wife was rich (over 43000 livres courantes). AEG, René Prevost, vol. 1, p. 208, 14.1.1774, and Jean Gabriel Bernier, vol. 20, p. 375, 19.11.1793.

34 AEG, Dunant et Mercier, vol. 11, p. 248.

35 The sum a patient costs the administration of Geneva's hospital in the 1720's. Piuz 1985, 268.

36 Furrer 1998, 94-96.

37 BGE, Ms fr 5647/9, p. 21. 
lifestyle. ${ }^{38}$ Future expenses indicate that, married and with three children, Odier and his second wife spent something over 4000 livres courantes each year, four times the value of his 1774 income. Thus, Odier and his wife could have survived on their annuities, but not lived decently. As most of his colleagues, the physician had to complement his income with a medical living.

\section{Money in medicine?}

After having travelled to Britain and Scotland, Odier and his colleagues realised that medical services there were paid at a better rate than in Geneva. ${ }^{39}$ Money was traditionally a complicated question for physicians: fees were difficult to collect and services were valued poorly. ${ }^{40}$ In 1774 , newcomers had time on their side: the mean age of the group of established physicians was then 54 years of age. But they were numerous and caused a rapid progression of the offer on the local market. ${ }^{41}$ It was thus essential for each one to gain a medical reputation. Odier was dynamic in developing schemes destined both to enhance his reputation and to enlarge his practice. The spheres in which these were carried out were economic (offering medicine by subscription, forming a medical partnership), intellectual (publishing on medical questions and teaching medical subjects), political (downplaying irregular practitioners, offering medical expertise) and corporative (setting up a medical society). ${ }^{42}$ Individually, such strategies were not original and are found among earlier generations of physicians. The multiplication of different strategies by one person in a short period and the volume of Odier's medical publications were exceptional for Geneva and emblematic of a change in attitude of physicians of his generation. ${ }^{43}$

The only way to gauge success is through the volume of medical practice. Documents conserved do not include a comprehensive list of Odier's patients. ${ }^{44}$ Instead, one finds lists of payments made by patients in various account books. Payments are alternatively made by different members of

38 The income of the couple is based on the annuities mentioned in their wedding contract and an estimated 4\% interest on capital. The contract was signed on December 10th, 1773: AEG, Dunant et Mercier, t. 11, pp. 248-250.

39 Fees in Geneva were about 16 pence (10 sols) a visit whereas in Britain a physician often charged a guinea per visit: 16 times more. On medical fees in Britain, consult Loudon 1986, 66.

40 Among many Rawcliffe 1988; Daems 1985, 136-138.

41 The first years were difficult for many physicians: Siraisi 1997, 108; Brockliss 2002, 28-30.

42 Rieder/Louis-Courvoisier 2011, 598-603.

43 Rieder/Louis-Courvoisier 2011, 598-600.

44 Not all patients paid and some paid many years later as Odier complained himself (Odier 2011,113). Louis Marie Lavergne was payed for 80\% of his work (1774-1779); Johann Anton Grass 85\% (1751-1755) and James Miles Langstaff's accounts reveal that he was paid approximately half of his billings. Goubert 1992, 217; Daems 1985, 133f.; Duffin 1993, 49f. 
the same family, suggesting that, as the young Albrecht von Haller in Bern, Odier was a family physician. ${ }^{45}$ Listed patronymics are insufficient to ascertain precisely the social classes from which his patients came. Occasional additional information, mentions of status, public function, or occupation indicate that patients came from a wide social spectrum. Numbers of payments and visits (he is paid for about 3000 visits per year between 1787 and 1793) are signs of a dynamic medical practice, a reality which is confirmed both by contemporary observers and by Odier's own correspondence.

The progression of the number of payments received by Odier (fig. 2) is not regular, but accidents can be explained by factors external to medical practice, namely the death of his wife (1779) and the economic disaster set off in Geneva by the financial crisis in France (1786-1798) ${ }^{46}$ The initial decline in practice (1787) seems to have been countered by extra publicity gained by publishing medical counsels in the local newspaper and by manning a gratuitous inoculation campaign for the poor in late 1787 and early $1788 .{ }^{47}$ Gradual decline in practice in the 1790's must be associated, as Odier himself noted, with both the economic and political crises that then hit Geneva. The graph of his gross medical income (fig. 3) follows that of payments made (fig. 2), although the former does climb faster than the latter. This is a first indication of a growing reputation: the mean cost of one visit was something under 1.2 livres courantes for the period 1774-1778 whereas it rose to 1.74 livres courantes between 1790 and $1793 .{ }^{48}$ Variations in the price paid

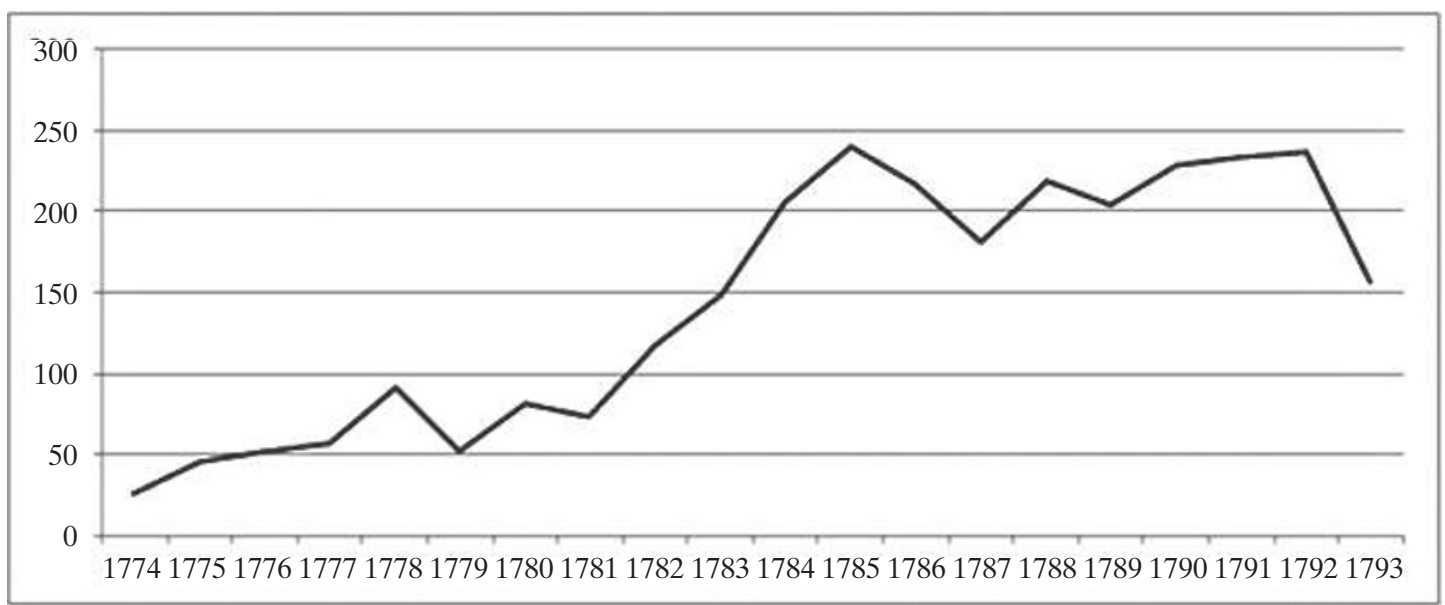

Fig. 2: Payments received by Louis Odier (1774-1793).

45 See Steinke 2008, 82f.

46 The mature physician Johann Anton Grass rarely billed more than 300 patients each year (1751-1755). Daems 1985, 132.

47 Odier himself believed that the inoculation campaign boosted his popularity. BGE, Ms fr. 4158, M 23, Louis Odier to Daniel De la Roche, Genève, le 3.1.1788.

48 BGE, Ms fr 5647/9. 


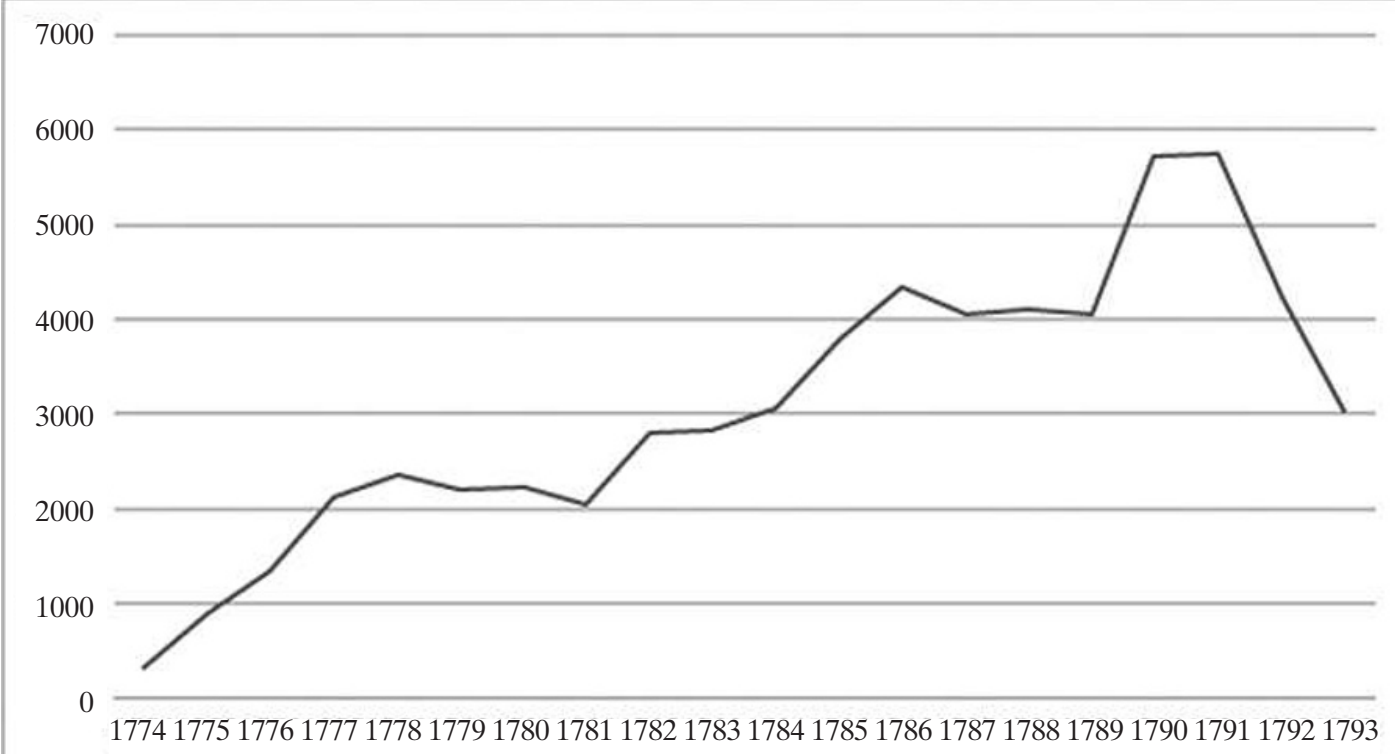

Fig. 3: Louis Odier's medical income (1774-1793) in livres courantes (Source: BGE, Ms fr 5647/9).

for a given service remained important as the well-embedded tradition of adapting billing to patients' status was common. ${ }^{49}$ That said, even at an early stage, Odier's services were relatively expensive: a physician's visit costed approximately the price of a day's wage for an agricultural worker or of six pounds of bread. ${ }^{50}$ This may lead one to believe that the physician cared mainly for the rich. And yet, account books are not the best source to ascertain the number of poor the physician cared for. Physicians were expected to treat the poor for free and such activities would have left few administrative traces. ${ }^{51}$ Treating the poor could, Odier recognised the fact himself, contribute to the making of a reputation. ${ }^{52}$ In the 18 th century, Geneva physicians do not seem to have systematically treated poor patients for free as charities routinely employed physicians to care for the poor. Between early 1775 and late 1780, Odier himself took care of the poor at Saint-Gervais, the artisan

49 At least since the late Middle Ages, see Rawcliffe 1988, 61f; Wear 2000, 20f.; Goubert 1992, 219. Odier argued for a scale of prices depending on a long list of variables, including the danger incurred by the physician's reputation, the efficiency of his care, the difficulties related to the cure, etc. See Odier 2011,109-114.

50 Prices are difficult to follow. For bread and workers salaries, see O'Maly 1954, p. XIII, and Piuz 1985, respectively. Interestingly, in XIXth century Ontario, the price of a medical visit was also the equivalent of a day's work for a labourer. Duffin 1993, 47.

51 Voir les Ordonnances du 15 février 1658, «Ordonnances particulières pour les Docteursmédecins», art. 8, cité dans Gautier 2001, 627.

$52 \mathrm{He}$ considered treating the poor as a means of enhancing his reputation. See letters written to his fiancée in 1772. For instance: BGE, Ms fr 4151, Louis Odier à Suzanne Baux, Londres, 21.11.1772. His hospital salary was, in 1780, 65 livres courantes, that is barely $3 \%$ of his income for that year. BGE, Ms fr 5647, p. 47. 


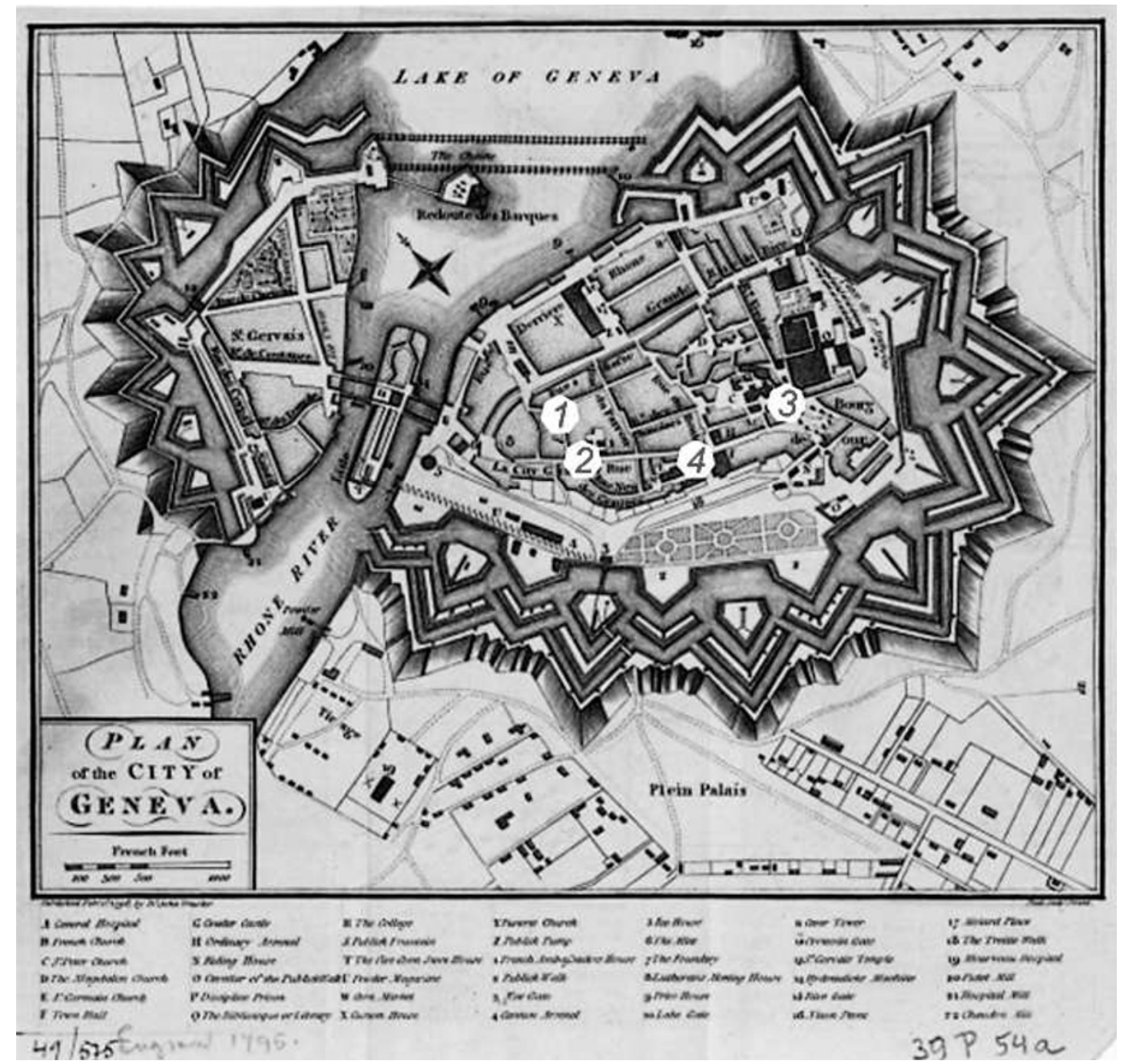

Fig. 4: Louis Odier's successive addresses (Bibliothèque de Genève [CIG]: "Plan of the city of Geneva", 1796).

district, on behalf of Geneva's hospital. ${ }^{53}$ The pay was bad, but welcome at that stage of his career.

Renouncing treating hospital outpatients in 1781 put an end to his regular attendance of the sick poor and yet, he does mention occasional visits to poor patients later in his career, interestingly, prompted by paying patients or patrons. ${ }^{54}$ What is obvious from the traces left by his philanthropic services is that the poor did not receive the same medical treatment as the rich:tending

53 AEG, AA 107 Registre du 4 juin 1777 au 20 avril 1785, p. 253, 3.1.1781. He does list a number of poor patients in 1775, his first year as a hospital physician. BGE, Ms fr 5647/9, p. 13.

54 In 1794, he visited in Nyon "some poor people" recommended to him by Mme Coucler (who had paid two bills worth over 100 livres courantes). In May 1803, he had an accident with a boarder on returning from a visit to a poor patient in Cologny. BGE, Ms fr 4158, N. 18, Louis Odier à Daniel De la Roche, 29.1.1794; Ms fr 5657, cahier 14, p. 75. 
the poor for a physician was an occasional activity, made of isolated visits rather than constant attention. This is confirmed by the treatment given to patients from modest backgrounds or, more precisely, the way such patients used the physician's services. In order to assess this, it is necessary to analyse in some detail Odier's account books. ${ }^{55}$ Relating numbers of visits to payments was then a common solution to draw up invoices. ${ }^{56}$ His account book only lists the number of visits, but as for other physicians, travel, time and difficulties justified higher bills. ${ }^{57}$ Prices were also adapted to the status of the patient. ${ }^{58} 102$ payments $(3.5 \%)$ were made by people who paid less than one livre courante (10-13 sols) and generally for only one visit. It is true that others also paid comparably small amounts per visit, but they called the physician more frequently, and paid thus much larger bills. Miss Goodet, for instance, paid the physician 58 livres in 1775 for 116 visits; the price paid for each service was low, but the total sum paid would have been beyond the means of unqualified manual workers and many artisans. The main distinction between the bad payers and patients of modest means is the mode of payment:rich and well-to-do patients preferred to pay at the end of an illness or at the end of the year. Less affluent patients - servants, peasants and artisans, sometimes explicitly named as such in his account book - paid directly for each and every service. Logically, they refrained from multiplying consultations and the subsequent expenses incurred. They typically used the physician's services on a one-time only basis. ${ }^{59}$

The group of poor paying patients was in fact smaller than it may appear, their being only 47 different patronymics among the 102 individual payments. This is not because poor patients came back to consult over the years, but because they paid for each and every service and came back once or twice within a few weeks, always paying immediately the service received.Typically, patients who paid small amounts did not become regular clients and discontinued using the physicians' services within the year. In short, the working

55 All payments made between January 1774 and February 1794 were processed in an excel file and amounts paid were equated to the related number of visits with the exception of the period 1779-1786 when the information on numbers of visits is not available.

56 Odier defends this practice in his discussion of medical billing. Odier 2011,109-112 \& 116f.

57 See Goubert 1992,219-221; Duffin 1993,47. Odier, for instance, treated the baron of Prangins in December 1786. This included one trip by night to Prangins, a second trip to the same place by day and approximately 2 days away from his practice. In his account book, this counts as two visits, but the physician was paid the handsome sum of 58 livres courantes and 2 sols for his services. BGE, Ms fr 5647/9; Guiguer 2007, t. 3, 255-257.

58 Odier 2011, 115.

59 This tends to confirm a statement made by Odier that the low cost of medical services in Geneva led physicians to charge all patients. Glasgow University special collection, Ms Cullen 138, Louis Odier à William Cullen, London, 23. 1772. 
poor rarely came back after a first experience as a patient. ${ }^{60}$ This may not be innocent. The physician was geared up to convince the affluent to come back, not the working poor. The parsimony with which the poorer patients used his services contrasts sharply with treatment demanded by richer patients. When ill, they saw the physician regularly once a day and, in times of crisis, more often. ${ }^{61}$ A good example is the Saussure family. Albertine Amélie de Saussure fell ill and was treated by Odier who was then the family's regular medical advisor. Between her first symptoms on October 27th, 1789, and her departure for a cure at Aix-les-Bains, May 18th, 1790, Odier appears 58 times in the notebook kept by the patient's husband. The physician then lived just a few minutes' walk from the Saussure residence. It is therefore not surprising that Odier often started out on morning calls just after 9 am, with a visit to Mrs. Saussure. The physician's name regularly comes back more than once in a daily entry, and sometimes even more often. On January 27th, 1790, the physician saw his patient 3 times. ${ }^{62}$ That said his name is only quoted when he had something to say or suggested a change in therapy. He clearly visited more than the 58 occurrences mentioned in the notebook suggest: he finally billed the Saussure family 364 visits during the years 1789 and $1790 !^{63}$ Affluent Geneva families such as the Saussure, regular clients, were the bread and butter of Odier's practice. Just 176 families paid the 277 most expensive invoices, amounts between 50 and 871 livres courantes, making up over half of the physician's income during his first twenty years of practice:31 326 livres courantes, 6 sols and 5 deniers (52\%). Removing travelling foreigners who also paid hefty bills, there remain 150 Geneva families ${ }^{64}$ who made up the core of Odier's medical income. ${ }^{65}$ In between the poor and the rich figure less well-off patients, artisans and petty bourgeois, the bulk of the physician's clientèle and almost half of his income. Odier treated and was paid by all but the destitute.$^{66}$ His medical income was, all in all, quite considerable: he was earning over 4000 livres tournois after 8 years, a sum Esprit Calvet took 20 years to attain. ${ }^{67} \mathrm{He}$ lived well from his practice in the early 19 th century.

60 An exception is M. Roget De la Chana who used Odier's services in 1785 for the first time and came back regularly during the following two years.

61 This was then common practice, for instance Steinke 2008, 84.

62 BGE, Archives Saussure 93.

63 According to his account book, Odier received 581 livres courants for 364 visits on January 2nd, 1791. BGE, Ms fr 5647/9, 81v.

64 When, as was customary, patients were given two family names, these were assimilated to single occurrences of the one name.

65 In order to be precise, it is necessary to include payments made by the same families of sums below 50 livres courantes. This has not been possible here.

66 Odier 2011, 100.

67 One livre courante of Geneva was worth 1.65 livres tournois. Thus Odier's income was considerably higher than Esprit Calvet's by 1782. See Brockliss 2002, 29. 
His economic situation remained unusual, contrary to other physians, Calvet, Lavergne and Langstaff for instance, ${ }^{68}$ he did not invest in property and practice remained his main source of income. ${ }^{69}$

\section{Growing reputation and professional marketing}

Reading through Odier's account book gives some indications about the evolution of the physician's reputation. During the first six years, all of his patients lived within Geneva's town walls. In 1780, the seventh year of his practice, two patients travelling from external locations are listed: one came from Cointrin, a locality to the northeast, just beyond the city walls, and the other from the Voirons, a region of Savoy, some $20 \mathrm{~km}$ distant. These two occurrences are emblematic of later trends: ever more patients came either from the immediate neighborhood of the town (Carouge, Plainpalais, Prél'Evêque, etc.), or from localities within a radius of some $80 \mathrm{~km}$ (Saint-Claude, Annecy, Morges, etc.). Numbers progressed yearly and by 1789, Odier's account book mentions 22 patients coming from relatively distant towns and villages (La Roche, Saint-Claude, etc.) and 6 from villages just beyond the town. ${ }^{70}$ Evidence tends to suggest that the physician did not leave the town for relatively modest fees and the phrasing used in the account books suggests that all but the rich patients travelled themselves. ${ }^{71}$ This last point is confirmed by Odier himself. When discussing the medical case of a peasant woman, "living fifteen leagues from my house", he had treated with arsenic for skin cancer, he insisted on an improvement he had noted "when she came to see me for the last time". ${ }^{72}$ The regular presence of such patients confirms the fact that Geneva attracted, well into its hinterland and beyond, sick people in search of quality orthodox medical services. Among foreigners, figure aristocratic British travelers, noblemen and noblewomen from Savoy, France and the German states. This clientèle paid well, and indeed, the progression of the price paid per visit between the 1770's and the early 1790's must be at least partially attributed to fees paid by members of this group.

68 Esprit Calvet lent money before the Revolution and bought property afterwards. See Brockliss 2002, 58-62; Duffin 1993, 52-58; Goubert 1992, 224-227.

69 Odier lost his savings and the fortune he inherited from his father by speculating on life annuities in the 1780's.

70 This is a conservative estimation. Following the same patient shows that indications of origin are not systematic.

71 He uses the preposition «de» before the said locations suggesting provenance rather than him travelling to (which would be «à»).

72 Odier 1811, 71-73. 
The Physician's best client ever was Prince Edward of England ${ }^{73}$ who paid 871 livres courantes, 10 sols for 156 visits on the 30 March 1790. The regular presence of foreign aristocrats and affluent visitors among Odier's clientèle confirm that he was a sought out and respected physician. Such patients were a good source of income, but they vanished as leisure travel subsided in the Revolutionary years.

Odier offered his medical services in a relatively confined area. How did he attract patients? How did he behave in society? Today almost any public act or statement can be read as a professional strategy. It is in fact difficult to distinguish the citizen from the physician, an interesting indication in itself. Caution must thus be observed when interpreting data and in the following paragraph, emphasis has been placed on isolating strategies which helped Odier gain "good patients" from affluent families. The first obvious point, self-presentation or dress, is barely substantiated. Observers rarely described the physician's clothing. Physicians traditionally wore dark coats over their clothes, suggesting the gravity of their calling. ${ }^{74}$ Unless one relies on vague allusions to the "gravity" or seriousness of his bearing, no documents indicate that Odier obeyed such conventions. On the contrary, he clearly followed the fashions of the group within which he was intent on working. Two occasions show him dressed in fashionable and even colorful garments, once in his own depiction of some new cloths and a second time in his daughter's description of his arrival in the mountain village of Chamonix wearing fashionable town attire. ${ }^{75}$ More apparent as a status symbol was his geographical positioning. Odier had grown up in the bustling commercial part of the town, the streets at the foot of the hill, on the left bank of the Rhone. His first professional address was slightly above this, «dans la montée», rue de la Pélisserie ("1", fig. 4). ${ }^{76}$ The road linked the commercial quarters with the upper town, the political center of the Republic and residence of the affluent Geneva bourgeois. In 1779, the year his first wife died, he moved into rented accommodation in the Grand Rue ("2", fig. 4). ${ }^{77}$ He was no longer "on the way up", but close to the heart of the upper town. The fact that Odier considered place of residence important is quite clear in the arguments he voiced in answer to his fiancée's request to move further east, closer to her parents' house at the

73 Prince Edward Augustus (1767-1820), the son of the George IIIrd.

74 This is particularly obvious in studies of Paris doctors. Lehoux 1976, 238, and Cabanès 1900 , esp. 7 \& 31.

75 The only distinctive object was a «chapeau de docteur», suggesting that he carried an attribute of his profession. But this is an isolated occurrence and it has not been possible to corroborate with the history of medical clothing codes. BGE, Ms fr 5656, 11 ${ }^{\mathrm{e}}$ cahier, pp. 21-22. See Louis-Courvoiser (in press).

76 AEG, Offices A / 4.

77 AEG, Offices A / 4. 
Bourg-de-Four. Although financial considerations led him to move there some years later (" 3 ", fig. 4), in 1779 , he refused, arguing that "the solidity of my establishment requires imperatively that I should be lodged as close as possible to the center of town, less for myself as I have good legs and to walk a little more or a little less is of no concern to me, than for the eagerness of the ill who consult me. I am sure that, in the long run, I would lose a lot to establish myself in a district as out of the way as the Bourg-de-Four." 78

This last location was close to the eastern limit of the town, but the commercial streets where he had grown up would have been both cheaper and closer to the geometric center of the town: ${ }^{79}$ Odier is in fact aiming for the center of the affluent streets around the cathedral. There are many reasons to explain this; the most obvious is that the sick called for familiar physicians and those who lived close by. Living among the affluent was a good strategy for developing a rich clientèle.

Entertaining polite and agreeable social relations with his clients was important, as were place of abode and dress. Among activities which did contribute to enlarge his social network in the right fields was the role he chose to play in philanthropic, scientific and editorial endeavors. These were numerous and would be too long to list in any detail. It suffices here to note that Odier was active and particularly visible on the local scientific scene. ${ }^{80}$ More revealing is his political positioning. Geneva's elite was divided into two opposing groups. The families of the oligarchy in power and their allies, the Négatifs, on one side and the citizens contesting the power of the former group and demanding a part in decision making, the Représentants, on the other. Odier's family figured logically among the second group, and yet the physician decided to avoid taking sides. "The political situation is ever more muddled," he wrote to his fiancée in 1779 , "and given the bitterness of both parties, their mutual suspicions, their inability to find solutions amicably, it is difficult to guess where all their quarrels shall lead us [...]. For myself, I have decided to always remain neutral, both because I do not have the leisure to consider each and every issue seriously, and because I meet every day people of both parties who I do not want to upset [...] and finally because my calling as a physician and my natural inclination entice me to sit on the fence. I shall always act accordingly." ${ }^{\prime 1}$

78 BGE, Ms fr 5654.

79 He finally moved to the Bourg-de-Four in 1793 ("3", fig. 4). Two years later, he moved again, this time to a big apartment which allowed him to take in boarders ("4", fig. 4).

80 Prominent here are his undertakings as member of the Société des Arts and his contributions as a medical author to the Journal de Genève (1787-1792) and later to the Bibliothèque britannique.

81 BGE, Ms fr 4153, F 33, Louis Odier à Andrienne Lecointe, s. 1. [Genève], s. d. [1779]. 


\section{Fashioning the (new) profession}

Clothing, lodging and politics were important questions the physician had to deal with while striving to make an imprint on the medical market. Practitioners had to adapt to social constraints in order to be credible. The ensuing image of the professional is that of a passive figure, adapting to social realities. Odier's professional posture and prose suggest a more active attitude. In his early career, between 1774 and 1798, he defended the notion that physicians' knowledge and expertise should be officially recognised. In 1798, when Geneva became French, the guild was suppressed, surgeons were granted academic status (and thus acquired a similar status to physicians), and a new subaltern status, the officier de santé was invented. ${ }^{82}$ Odier can only have had sympathy for most of these transformations. Systematic licensing was a powerful measure taken against irregular healers and the suppression of the guild in Geneva enabled him to become a professor in medicine at Geneva's Academy (1799), a status the guild had until then refused him..${ }^{83} \mathrm{He}$ was, that said, wary of the possible consequences of the legal merging of the professions of surgery and of medicine (law of Ventôse an XI). His point of view was here conservative. In his eyes, the danger stemmed from the confusion of roles: clients might see "doctor surgeons" as physicians who could operate and physicians as healers who could not. He worried about the loss of hands on experience for surgeons and about the negative financial effects on physicians' incomes. Considering the professional situation induced him to construe a positive image of the physician:

A vast number of good physicians [...] possess the genius of observation, assurance in evaluating a condition [sureté de leur coup d'œil], great medical tact and excellent studies which render them quite capable of practicing medicine itself with great success. ${ }^{84}$

This positive image may be associated with Odier's ethical, economic and professional considerations on physic. And yet there were other motivations. The political and economic crisis of the day had ruined his economic situation. His fortune was swallowed in the French financial crisis (1787-1801) and his medical income collapsed after 1793. Odier survived by taking in boarders and thanks to support given by his wife who developed a business importing and selling fabrics. The experience left him with hands-on knowledge of the physician's financial fragility. ${ }^{85}$ This is why Odier took great pains

82 For a detailed analysis of the reform of the French practitioners, see Léonard 1979, t. 1, 254-302. For social effects on practitioners, see Faure 1994; Ramsey 1988.

83 Rieder 2009, 24-27.

84 Odier 2011, 89.

85 See BGE, Ms fr 5656, $10^{\text {e }}$ cahier. 
to consider how physicians could earn a decent living, claiming that they should be financially independent.

He argued that society should enable a physician to live decently, continue research on medical questions and preserve time for family and various philanthropic activities. The price a visit should cost must thus be established by evaluating both the time the physician could spend practicing medicine and the income he needed in order to live decently. His estimations led him to propose the price of about 25 sols per visit; he was in fact suggesting an increase in fees. ${ }^{86}$ Arguing for a common norm in payment, Odier imagines a common professional attitude and outlook. This is confirmed by his ideas on medical confidentiality. He argued that physicians should no longer exchange information about their patients with third parties. The practice of giving out information was then widespread. Physicians were sought out by worried fiancées and fiancés and questioned on past health of potential spouses. Arguments he put forward to defend the necessity of unconditional secrecy were multiple, but all were articulated around the patient's interests: the risk of making a medical error by interpreting a past disease as a hereditary condition, the danger of reinforcing popular prejudices when medical knowledge was hazy, and beyond all, the peril of abusing the trust the patient had placed in the physician by diffusing information that might bear consequences on the patient's life. In short, he defended a conception of medical behavior which depended not on social expectations or the physician's interests, but on the interests of the patient: a professional attitude. ${ }^{87}$

\section{The physician and the market: conclusion}

Odier's career offers a partial view of the medical marketplace only, and yet it confers a certain depth to the social reality of the market. Working on individual practitioners is important for understanding social practices. As a physician, Odier did play a role in the health of individuals from a wide array of social backgrounds; he tended hundreds of different patients every year. He was active, visited his patients for several hours a day and was on call seven days a week. The status of each patient was important and the physician's function was not the same in each social setting. For many people of modest means he was probably the last of a list of healers. Only the rich called him systematically and even they often also consulted other practitioners.

86 Odier 2011, 109.

87 His argumentation is based on a casuistic taken from his own practice. Odier 2011, 143-163. 
Economically, Odier was fragile, the practice of his art was not highly valued by all and money was a problem during most of his adult life. In order to earn a decent living, he had to gain the confidence of a small group of rich patients and this explains why the doctor may be portrayed as being a well-integrated, but passive member of society. The ideal posture of the physician was that of a friend. He could be neither a political enemy nor a stranger to his patients. The physician clung to traditional values which distinguished his professional figure from those of the competition: knowledge, social belonging and altruism. The last he tried, in a traditional mode, to build on in order to encourage the affluent to pay more.

This is not to suggest that Odier was a greedy professional, but that focusing on an individual does bring a certain historical depth. The physician was obliged to a certain extent to fit into the mould society had prepared for him, despite the idealised conception he held of medical practice at the outset of his career. The activities he deployed to develop his professional credibility were at first for his own use, but in the last decades of his practice, the years when he pondered about the nature of his profession, he clearly aspired to share his experience and conclusions with his colleagues. This, encouraged by the contemporary reform of medical occupations, may be described as the expression of a new professional dynamism and an effort to offer norms of practice to the public. The freedom of thought possible in France enabled Odier to consider all patients on the same footing and construe a positive image of the physician: a figure at the forefront of medical research, a member of a (professional) group and a defender of the confidentiality of his patients' secrets, in other words, a coherent professional figure.

\section{Bibliography}

Bonner, Thomas Neville, Becoming a Physician (New York 1995)

Brockliss, Laurence, Calvet's Web: Enlightenment and the Republic of Letters in Eighteenthcentury France (Oxford 2002)

Brockliss, Laurence/Colin Jones, The Medical World of Early Modern France (Oxford 1997)

Broman, Thomas H., "Rethinking Professionalization: Theory, Practice, and Professional Ideology in Eighteenth-Century German Medicine", The Journal of Modern History 67 (1995) 835-872

Cabanès, Augustin, Le costume du médecin en France de Molière à nos jours (Paris 1900)

Cook, Harold J., Trials of an Ordinary Doctor: Joannes Groenevelt in Sventeenth-Century London (Baltimore 1994)

Daems, Willem F., Johann Anton Grass von Portein 1684-1770 (Chur 1985)

Duffin, Jacalyn, Langstaff: a Ninenteenth century Medical Life (Toronto 1993)

Faure, Olivier, Histoire sociale de la médecine, XVIII $-X X^{e}$ siècles (Paris 1994)

Furrer, Norbert, «Le coût de la vie à Lausanne en 1798», in: François Flouck, Patrick-R. Monbaron et al. (eds), De l'ours à la cocarde (Lausanne 1998) 79-96 
Gautier, Léon, La médecine à Genève jusqu'à la fin du $18^{e}$ siècle (Genève 1906, repr. Genève 2001)

Goubert, Jean-Pierre, "The Extent of Medical Practice in France around 1780", in: Patricia Branca (ed.), The Medicine Show. Patients, Physicians and the Perplexities of the Health Revolution in Modern Society (New York 1977) 211-228

Goubert, Jean-Pierre, Médecins d'hier, médecins d'aujourd'hui. Le cas du Docteur Lavergne (1756-1831) (Paris 1992)

Guiguer, Louis-François,Journal, 3 vols, Rinantonio Viani/Chantal de Schoulepnikoff et al. (eds) (Prangins 2007)

Harley, David,"Bred up in the study of that Faculty: Licensed physicians in North-West England, 1660-1760", Medical History 38 (1994) 398-420

Jenner, Mark S. R./Patrick Wallis, "The Medical Marketplace”, in: Mark S. R. Jenner/Patrick Wallis (eds), Medicine and the Market in England and its Colonies, c.1450-c.1850 (Basingstoke [England] 2007) 1-23

Julia, Dominique/Jacques Revel, «Les étudiants et leurs études dans la France moderne», in: Les universités européennes du XVI au XVIII ${ }^{e}$ siècles. Histoire sociale des populations étudiantes (Paris 1989)

Kibleur, Pascale, «L'évaluation et la validation des remèdes par la Société Royale de Médecine (1778-1793)», in: Olivier Faure (ed.), Les thérapeutiques: savoirs et usages (Oullins 1999) 73-85

Lehoux, Françoise, Le cadre de vie des médecins parisiens aux XVI et XVII siècles (Paris 1976)

Léonard, Jacques, Les médecins de l'Ouest au XIX' siècle, 3 vols (Lille 1978)

Lescaze, Bernard, Genève, sa vie et ses monnaies aux siècles passés (Genève 1981)

Loudon, Irvine, Medical Care and the General Practitioner (1750-1850) (Oxford 1986)

Louis-Courvoisier, Micheline, «Rhabilleurs, experts, chirurgiens, sages-femmes et pasteurs: les malades et leurs soignants en Suisse romande au XVIII' ${ }^{\mathrm{e}}$ siècle», in:Vincent Barras/Micheline Louis-Courvoisier (eds), La médecine des Lumières: tout autour de Tissot (Genève 2001) $187-200$

Louis-Courvoisier, Micheline, «Aspirations éthiques et réalité de la pratique médicale à la fin de l'Ancien Régime», Bulletin canadien d'histoire de la médecine 29 (2012) 29-48

Mandrou, Robert, «Les Français hors de France aux XVI ${ }^{e}$ et XVII ${ }^{\mathrm{e}}$ siècles», Annales: histoire, sciences sociales 14 (1959) 662-666

Mandrou, Robert, «Les protestants français réfugiés à Genève après la St-Barthélémy», Revue Suisse d'Histoire (1966) 243-249

Odier, Louis, Extraits d'un ouvrage du Dr Alex. Flajani (Genève 1811)

Odier, Louis, Les honoraires médicaux et autres mémoires d'éthique médicale (Paris 2011)

O'Maley, Patrick F., Geneva in the Eighteenth Century: A socio-economic study of the Bourgeois city-state during its Golden Age, unpublished $\mathrm{PhD}$, University of California (Berkeley 1954)

Perrenoud, Alfred, La population de Genève du XVI ${ }^{e}$ au début du XIX ${ }^{e}$ siècle (Genève 1979)

Piuz, Anne-Marie, «Jean Vian, ouvrier italien réfugié à Genève (vers 1690-1772)», in: A Genève et autour de Genève aux XVII et XVIII siècle (Lausanne 1985) 262-273

Ramsey, Matthew, Professional and Popular Medicine in France, 1770-1830: The Social World of Medical Practice (Cambridge 1988)

Rawcliffe, Carole, "The Profits of Practice: the Wealth and Status of Medical Men in Later Medieval England", Social History of Medicine 1 (1988) 61-78

Revel, Jacques (ed.), Jeux d'échelles: la micro-analyse à l'expérience (Paris 1996)

Rieder, Philip, «Médecins et patients à Genève: offre et consommations thérapeutiques à l'époque moderne», Revue d'histoire moderne et contemporaine 52 (2005) 39-63.

Rieder, Philip, Anatomie d'une institution médicale: la Faculté de médecine de Genève 1876-1920 (Genève 2009)

Rieder, Philip, "Miracles and Heretics: Protestants and Catholic Healing Practices in and around Geneva 1530-1750", Social History of Medicine 23 (2010) 227-243

Rieder, Philip, «La médicalisation en question. Genève, l'Ancien Régime et la demande médicale», Bulletin de la Société d'histoire et d'archéologie de Genève (2011) 3-31

Rieder, Philip/Christine Tourn, «Les Conseils et la santé: histoire d'une autorité médicale laïque», in:Sandra Coram Mekkey (ed.), Les registres du Conseil de la République de Genève sous l'Ancien Régime, nouvelles approches, nouvelles perspectives (Genève 2009) 
Rieder, Philip/Micheline Louis-Courvoisier, "Enlightened Physicians: Setting out on an Elite Academic Career in the Second Half of the Eighteenth Century", Bulletin of the History of Medicine 84 (2010) 578-606

Risse, Guenter, "Medicine in the Age of Enlightenment", in: Andrew Wear (ed.), Medicine in Society (Cambridge 1992) 149-195

Siraisi, Nancy G., The Clock and the Mirror: Girolamo Cardano and Renaissance Medicine (Princeton 1997)

Steinke, Hubert, «Der Junge Arzt und seine Patienten: Albrecht von Hallers Praxis in Bern 1731-1736», in:Elisabeth Dietrich-Daum/Martin Dinges et al. (eds), Arztpraxen im Vergleich: 18.-20. Jahrhundert (Innsbruck 2008) 79-86

Wear, Andrew, Knowledge and Practice in English Medicine: 1550-1680 (Cambridge, etc. 2000) 